\title{
Interaction of Technological Marketing and Porter's Five Competitive Forces on SME Competitiveness in South Africa
}

\author{
Progress Hove \\ Department of Business Management, Vaal University of Technology, South Africa \\ Reginald Masocha \\ Department of Business Management, University of Limpopo, South Africa \\ E-mail: rmasocha@gmail.com
}

\section{Doi:10.5901/mjss.2014.v5n4p254}

\begin{abstract}
Principally, this study sought to investigate the influence of technological marketing on Porter's five competitive forces model of SMEs in the Buffalo City Metropolitan Municipality. The research problem, herein, arises from a theoretical and pragmatic gap around the lack of consensus between the positive and negative impacts of technological marketing developments on industry structure. The study employed a quantitative method in data collection from a sample of 211 SME owners/managers in the retail and manufacturing sectors of Buffalo City Metropolitan Municipality, South Africa. The sample data was analysed using SEM. The principal finding of this study reveals that technological marketing has no significant impact on Porter's five competitive forces. The findings have important implications for enhancing the adoption of new technologies in marketing SME products/services.
\end{abstract}

Keywords: Technological marketing, Porter's Five Competitive Forces Model, SMEs, Competitive Marketing

\section{Introduction}

Small and Medium Enterprises (SMEs) like other firms are today needful of strategies resulting in a competitive advantage on the face of technologically competitive business environments. Almost all firms across all industries are challenged, by the inherent effects of persistent technological developments as businesses increasingly emphasise the utilisation of the latest accessible technologies when conducting business and competing with each other (Masocha et al., 2011). Technology is a force that is inexcusably leading the redefining of the competitive spectrum for firms and their interaction with customers. With survival and success of SMEs being topical in research worldwide because of developmental roles, such as job creation, that small firms fulfil globally. Thus, the impact of technology on SMEs in competitive marketing in their markets warrants a detailed investigation. Prominently, SMEs are strategic in developing countries where they are deemed instrumental for poverty alleviation (McCartan-Quin \& Carson, 2003). Consequently, extensive emphasis has been placed on SME owners/managers management towards the competitiveness and survival of SMEs.

In marketing, technological marketing has sprouted as a discourse which deals with the planning and execution of conceptualising, pricing, distributing and promoting products, which occurs through technology. Technological marketing is the imperative center and extensive driver of business activities and competition, since the superior goal for a firm is to satisfy the customer (Masocha et al., 2011). Technology and competition have become major challenges pervasively impacting on firms in contemporary markets. Increasingly, the industry structure and elements of competition seem to be detrimental, particularly in instances where firms are lagging behind with advanced marketing technology systems. Conversely, from the customers' side, opportunities exist which enhance switching mobility in the market for those customers who are acquainted with technology. As technological utilisation continues to drive consumers in many industries, the fundamental problem driving this paper is the need to know whether technology (independent variable) constrains or strengthens the competitiveness and performance of SMEs in the business environments (dependent variables). Therefore, this paper investigates the compatibility and prevalence of technological marketing and Porter's five competitive forces, by focusing and competitiveness of SMEs. 


\section{Theoretical Background}

The theory in the field of technological marketing is still in its infancy and the outcome of immense technological developments and utilisation on industry structure and firm performance has not been fairly investigated, particularly in SME marketing. This posits a disparity in SME marketing given the prevalent prioritisation of technological marketing tools, such as the Internet, which provides benefits such as wide information availability which substantially reduces marketing challenges. Thus, the position of SMEs in profiting from technologically competitive marketing environments needs substantiation in emerging markets, such as South Africa. Thus, there is no general consensus on whether today's rapid pace of technological change makes subsequent industry structure and competition favourable or unfavourable towards SME marketing in South Africa.

\subsection{Porter's five competitive forces model}

First published in 1980, and modified in 2001 and 2008, Porter's model consists of five competitive forces, namely; bargaining power of suppliers, bargaining power of customers, threat of substitutes, threat of new entrants and rivalry among existing firms. With the recent advent of technology, the question is: are these five competitive forces affected, negatively or positively? Emanating from technological evolvement and extreme competition, business practices and strategies are changing so as to adopt superior standards across all business activities. Although previous studies (Adeyemi, 2009; Trainor et al., 2011) were conducted on the impact of technology on the competitive marketing of firms, less focus was placed on how technology modifies Porter's original model. The redefinition of the model, so far, manifest in the addition of a sixth force known as the complementary relationships (Ghazanfar et al., 2000, Grant, 2002 \& Adeyemi, 2009).

This model used herein generally entails that the ultimate impact of the five forces determines the level of competition in industry as well as the profitability thereof. The model is fraught of its criticisms; inter alia, the question on the appropriateness of developing and analyzing the corporate strategy at industry level rather than firm level, failure to take into account the heterogeneity within an industry, capability of firms to raise industry entry barriers individually or collectively, and lastly the consistence of earning above-normal profits (Rodie \& Martin, 2001). However, the model still commands substantive grounds as an instrument of assessing competition. For SMEs as in other industries, Porter's model states that the weaker/stronger the forces are, the more/less attractive the industry becomes as a whole as well as its overall profits.

\subsubsection{The threat of new entrants}

Potential and firms that have recently entered the market and industry to share the profits enjoyed by already existing firms in the same market contribute towards the threat of new entrants to any industry (Hellriegel, et al, 2004:106). New firms to an industry are driven by profitability of an industry as well survival chances. The threat of new entrants depends on that industry's barriers to entry. For instance, the economies of scale required to be successful can provide a barrier to entry, thereby reducing competition. Electronic marketplaces and new technologies are advantageous for new competitors due to demising of entry barriers such as incumbents' locational advantages. Also the technological front accentuates the entrants of new competitors and making difficult for incumbents to recognise and react to new competitors (Rodie \& Martin, 2001).

$\mathrm{Mol}$, Chiu \& Wijnberg (2012) opine that technological impact on industry dynamics is two-thronged. Firstly, new technologies are identified as competence-enhancing whereby the dominance of incumbents is strengthened. This is when huge technological investments turn out to create barriers of entry for potential entrants (Louw \& Venter, 2010:219). Secondly, competence-destroying technologies nullify and mitigate the required economies of scale in an industry, hence, reducing barriers to entry and ultimately increasing the propensity of newcomers. SMEs can both be either incumbents or the potential entrants as such how technology impact them depends with their position. While technology accentuates SMEs as far as the threat of potential entrants is concerned by dampening barriers of entry (Mol et al., 2012; Rodie \& Martin, 2001), unfortunately technology seems to create exit barriers in the form of sunk costs. This eventually dampens the profitability of that particular industry and intensifies competition as once a firm has entered a particular industry they are faced with a "do or die" scenario. 


\subsubsection{The threat of new substitutes}

A substitute product is a product that serves the same purpose as the traditional and original product of firms in the market (Louw \& Venter, 2010:218). The threat of substitutes increases where the firms' customers are willing to substitute the traditional product with a new one, where the new product/service offers relatively more benefits than the traditional one and where there are low switching costs. New technologies result in new products and services for consumers, improved existing products, better customer services and, often, lower prices; these lure customers towards switching and substituting the existing products with new ones (Boone \& Kurtz, 1992:56). Technological creativity opens up various distribution channels on the internet and electronic marketspaces (Rodie \& Martin, 2001), also destroys geographic and physical boundaries and accelerates the speed of flow of products in the distribution channel. The obvious result is that the number of substitute products accessing any market increases substantially. This calls for SMEs to think beyond their physical boundaries when assessing the substitute products spectrum. Both "Me-too products" with heightened points of parity and products offering unique selling proposition through distinctive points of differention are increasing as a result of technology.

\subsubsection{Rivalry among existing firms}

Competitive rivals are firms with similar products and services which are aimed at the same customer group (Louw \& Venter, 2010:217). This is the most obvious and immediate source of competition. Industry competition intensifies when a market is composed of numerous and almost balanced competing firms. Notably, competitors utilise strategies such as price-cutting, improved service delivery and quality (Hellriegel et al., 2004:104). New technology causes firms to face more difficulties in upholding proprietary offerings. This reduces differentiation and strengthens the rivalry which exists among these firms, hence, intensifying the overall SME industry competition (Porter, 2001:66). The increased competition allows customers to gain more bargaining power, as discussed below:

\subsubsection{The bargaining power of buyers}

The bargaining power of buyers refers to the ability of buyers/customers to force down the prices of the firms' products and services (Hellriegel et al., 2004:105). When the SME market is dominated by a small number of customers or where the customers constitute a large proportion of the SMEs' services, competition intensifies due to the high bargaining power of customers (Malcolm \& Martin, 2003:98). In addition, competition increases in an industry where customers threaten to integrate backwards (Hollensen, 2003:78). Technology provides a customer with a wider choice of channels through which to connect with a brand; this intensifies the switching and mobility of customers, thereby boosting buyers' bargaining power (Porter, 2001:66; Kotler \& Keller, 2006:13; Baker \& Bass, 2003:1-2).

\subsubsection{The bargaining power of suppliers}

The bargaining power of suppliers refers to the ability of suppliers to force up the prices of the inputs of firms in the industry (Hellriegel et al., 2004:106). The bargaining power of suppliers tends to be higher when the suppliers are concentrated or when they contribute to the larger component of the products that are bought by customers. Thus, suppliers can bargain for higher prices and thus reduce the profitability of the SMEs (Jain, 1997:91). Competition from suppliers is also increased when suppliers threaten to integrate forward (Malcolm \& Martin, 2003:98). New technology, which results in reduced barriers to entry, results in an increase in competitors as suppliers integrate forward. Ultimately, this tends to shift the bargaining power to suppliers, hence increasing competition (Porter, 2001:66). Thus, while deploying the marketing technologies has benefits, like expanding the market, such benefits come at the expense of firms' average profitability (industry attractiveness and competitiveness) (Spanos \& Lioukas, 2001:914).

\subsection{Porter's five forces model and Technological marketing}

Porter (2008:2) asserts that industry structure grows out of a set of economic and technical characteristics that determine the strength of each competitive force. Thus, having adequate knowledge of the competitive forces and their underlying causes provides a framework for anticipating and influencing competition and firm performance as measured by profitability over time (Louw \& Venter, 2010:250). Porter, thus, uses the five competitive forces model to define and 
explain industry structure and firm performance from a market-based perspective. Fundamental to the MBV of strategy is the concept of activities, since it views a firm through its strategy as a bundle of activities. According to Porter (2008:3), a strategy is a constant array or pattern of activities aimed at creating a specific form of competitive advantage for a firm which exists in two basic types, either the differentiation or low cost. More so, a firm needs to understand the sophisticated industry structure before it chooses a strategy. Industry structure thus, affects the sustainability of firm performance, whereas positioning reflects the firm's ability to establish competitive advantage over its rivals. Therefore, a firm can exercise its market power through the gained attractive position in order to create a competitive advantage that enhances firm performance (Spanos \& Lioukas, 2001:909).

Amidst a myriad of paradigms shifts and paradoxical approaches to marketing, technological marketing or emarketing has been accepted without much debate. Such that the documentation and theory is much scattered and is scarcely comprehensively discussed in literature. Technological marketing entails an ultimate transition in marketing thought and philosophies that has drifted in business unconsciously positing a complete shift in technological paradigms (Mol, et al., 2012). An assessment of the existing and relevant literature exposed that a key problem in extant literature is the distorted manner of dealing with the concept of, and defining, technological marketing. Notably, the majority of the researchers erroneously use the term technological marketing. Technological marketing, Internet marketing, Ecommerce and E-business have been used interchangeably based on the assumption that they are synonymous (Trainor et al., 2011; Strauss \& Frost, 2001). Per se, Technological marketing has a broader scope than Internet marketing. The definition of technological marketing, in this paper, includes Internet marketing tools, as well as, electronic marketing tools such as Intranets, Extranets and mobile phones (Trainor et al., 2011). Technological marketing (e-marketing) anchors on building and maintaining customer relationships through online activities in facilitating the exchange of ideas, products and services that satisfy the goals of both parties (Swanepoel, 2007). Undoubtedly, in this digitalised and computerised era, as marketing practices change towards taking advantage of new technologies, the implementation of customer value delivery coupled with electronic marketing resources is growing rapidly.

SME owners/managers are bound to respond to the threat, and test of success, by understanding and recognising the dangers of technological marketing deficiency, with regard to competition in their respective industries (De Klerk \& Kroon, 2005). Also important to note; contemporary marketing technologies firmly endorse the logic and consistency of the marketing process: situation analysis, marketing planning, strategy implementation and control. In order for SMEs to efficiently maximise the delivery of customer benefits and satisfaction, constant innovation towards the improvement of marketing strategies and processes, is a necessity (Reedy \& Schullo, 2004:5). Additionally, digital computing, data storage, and the transmittal of digital signals through telecommunication networks provide firms with an interactive marketing strategy which combines product features, product development, pricing, and customer information (Galbreath \& Galvin, 2007). Thus, through marketing technology, flexibility is increased and SMEs can better attract customers and efficiently respond to their demands, thereby enhancing their competitiveness in the market (Lamb et al., 2002). However, if incorrectly applied, marketing technologies could raise complex ethical issues and present significant threats (Walker et al., 2006).

A conceptual model is developed in Figure 1. The model consists of three basic constructs, namely the technological marketing, Porter's five competitive forces (industry structure) and firm competitiveness. Conceivably, the adoption of new marketing technologies in SMEs is expected to influence Porter's five competitive forces and firm competitiveness of retailing and manufacturing SMEs.

Fig 1: Conceptual Model

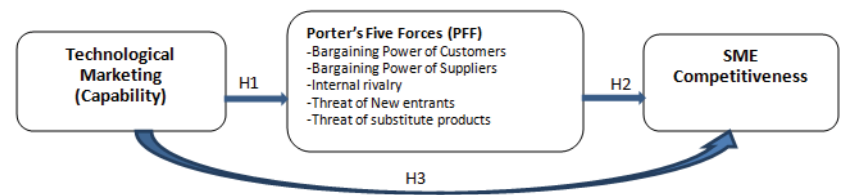

\section{Research Methodology}

\subsection{Measurement Instrument and Questionnaire Design}

The research measurements were operationalised, primarily, on the basis of previous works and consultation with field and academic experts. A review of the relevant literature resulted in three main constructs, i.e. technological marketing (e-marketing), Porter's five competitive forces model (used to measure industry structure) and firm performance. Minor 
modifications were made in order to suit the current research context/purpose and the opinions of experts. Technological marketing (e-marketing) was measured using an adapted five item scale instrument, employed by Powell and DentMicallef (1997) and Trainor et al. (2011:167-168). Alternatively, Porter's five competitive forces model (industry structure) was measured using a five item scale adapted from Galbreath and Galvin (2008:115-116). Finally, firm performance was measured using scales adapted from the works of Powell and Dent-Micallef (1997). Individual scales and their corresponding measurement items are printed in the Appendix section.

\subsection{Research Setting, Research Sample and Data Collection}

The current study investigated the impact of technological marketing (capability) on Porter's five competitive forces and firm competitiveness of retailing and manufacturing SMEs. Therefore, the sample unit of analysis was SME manufacturers and retailers (the owners/managers), especially in Buffalo City Metropolitan Municipality. The Small Enterprises Development Agency (SEDA) was selected as a sampling frame. By cooperating with SEDA, out of a total of 578 manufacturing and retailing SMEs in Buffalo City Metropolitan Municipality, 300 SMEs were randomly selected from the association membership database and the questionnaire were distributed to the SME manufacturing and retailing owners/managers. These participants were considered competent to evaluate their firms' competitiveness and performance in digital markets. Prior to the distribution of the questionnaire in person, these potential participants were contacted and informed of the significance of the current study by telephone. A total of 211 usable questionnaires were retrieved for the final data analysis, representing a response rate of 70 percent.

\section{Data Analyses and Results}

The research data gathered for this study was coded in short phrases to make it easier to enter into the analysing software, for further analysis. It was analysed using a two-step procedure, as suggested by Anderson and Gerbing (1988). First, the accuracy of multi-item construct measures was assessed, followed by a test of the research model and hypotheses. In both data analysis stages, this paper tended towards the use of the Structural-Equation-Modeling (SEM) technique. A Confirmatory-Factor-Analysis (CFA) was performed using Amos 7 in order to access the measurement model. In addition, Amos 7 was employed as the computation SEM software. The research sample is described below.

\subsection{Sample Description}

The sample profiles presented in Table 1 showed that $30 \%$ of the participating SME manufacturers and retailers employed between 6 to 10 workers, while, 32\% employed between 11 to 20 workers. Only $5 \%$ of the sample employed above 50 workers in their firms. More so, $65 \%$ of the participating SME manufacturers and retailers had less than 11 years of business operation experience, while $35 \%$ had experience of more than 11years, respectively. A majority of the participants (87\%) had sales of less than R1 million, while, the remainder (13\%) had sales of more than R1 million. The analysis also indicated that retailing SMEs (77\%) dominated the research sample, while, manufacturing SMEs constituted $23 \%$ of the sample.

Table 1: Sample Data

\begin{tabular}{c|c|c||c|c|c}
\hline \hline Number of Employees & Freq & $\%$ & Annual Sales Revenue & Freq & $\%$ \\
\hline$\leqq 5$ & 33 & 16 & $\leqq$ R100 000 & 7 & 3 \\
\hline $6-10$ & 63 & 30 & R100 000-300 000 & 49 & 23 \\
\hline $11-20$ & 67 & 32 & R301 000-600 000 & 73 & 35 \\
\hline $21-50$ & 38 & 18 & R601 000-1million & 54 & 26 \\
\hline$\leqq 51$ & 10 & 5 & $\geqq$ R1 million & 28 & 13 \\
\hline Total & 211 & 100 & Total & 211 & 100 \\
\hline Work Experiences & Freq & $\%$ & Industries & Freq & $\%$ \\
\hline$\leqq 2$ years & 5 & 2 & Retailing & 162 & 77 \\
\hline $3-5$ years & 67 & 32 & Manufacturing & 49 & 23 \\
\hline $6-10$ years & 65 & 31 & Total & 211 & 100 \\
\hline $11-20$ years & 61 & 29 & & & \\
\hline$\geqq 21$ years & 13 & 6 & & & \\
\hline Total & 211 & 100 & & & \\
\hline \hline
\end{tabular}




\subsection{Measurement Accuracy Assessment}

At this stage, a CFA (Confirmatory-Factor-Analysis) was performed to access the measurement model. Overall acceptable CFA model fit indices used in this study included: the chi-square value over degree of freedom $\left(X^{2} / \mathrm{df}\right)$ of value between 1 and 3, the values of Goodness-of-Fit Index (GFI), Comparative Fit Index (CFI), Incremental Fit Index (IFI), and Tucker-Lewis Index (TLI) equal to or greater than 0.90, and the Root Mean Square Error of Approximation (RMSEA) value to be equal to or less than 0.08 . Recommended statistics for the final overall model assessment revealed an acceptable fit of the measurement model to the data, including $X^{2} /(\mathrm{df})$ being $2.14, \mathrm{GFI}$ of 0.85 , RMR being 0.09 , CFI being 0.96 , NFI being 0.93 , IFI being 0.96 , TLI of 0.95 and RMSEA being 0.07 .

Table 2: CFA Model Fit

\begin{tabular}{|l|c|}
\hline \multicolumn{1}{|c|}{ FIT INDEX } & Results \\
\hline Chi-Square/ d. f. & 2.142 \\
\hline GFI (Goodness of Fit Index) & 0.847 \\
\hline RMR (Root Mean Square Residual) & 0.088 \\
\hline CFI (Comparative Fit Index) & 0.961 \\
\hline RMSEA (Root Mean Square Error of Approximation) & 0.074 \\
\hline NFI (Normal Fit Index) & 0.930 \\
\hline TLI (Tucker Lewis Index) & 0.952 \\
\hline IFI (Incremental Fit index) & 0.961 \\
\hline
\end{tabular}

\subsubsection{Research Model Assessment and Research Hypothesis Testing}

The research model was estimated and the hypotheses testing proceeded. As shown in Table 3, all the research model fit statistics were within or approaching to the acceptable ranges, i.e., $X^{2} /(\mathrm{df})$ being 1.899 , GFI being 0.87 , RMR of 0.07, CFI being 0.97 , NFI being 0.94 , IFI being 0.97 , TLI being 0.96 and RMSEA being 0.065 . The individual hypothesis testing results are also shown in Table 5 . The $\beta$ coefficients for $\mathrm{H} 1, \mathrm{H} 2$ and $\mathrm{H} 3$ were $-0.89,0.775$ and -0.135 , respectively.

Table 3: CFA SEM Results

$\begin{array}{lc}\text { Chi-Square/ d. f. } & \text { Results } \\ \text { GFI (Goodness of Fit Index) } & 1.899 \\ \text { RMR (Root Mean Square Residual) } & 0.874 \\ \text { CFI (Comparative Fit Index) } & 0.078 \\ \text { RMSEA (Root Mean Square Error of Approximation) } & 0.972 \\ \text { NFI (Normal Fit Index) } & 0.065 \\ \text { TLI (Tucker Lewis Index) } & 0.944 \\ \text { IFI (Incremental Fit index) } & 0.962 \\ \end{array}$

This paper hypothesised three linear relationships which are between technological marketing and Porter's five forces $\left(\mathrm{H}_{1}\right)$, technological marketing and SME competitiveness $\left(\mathrm{H}_{2}\right)$ and between Porter's five forces and SME competitiveness $\left(\mathrm{H}_{3}\right)$. As indicated in Table 4 below, of these 3 posited linear relationships, only one $\left(\mathrm{H}_{2}\right)$ was validated because it had a positive factor loading of 0.775 which is greater than the recommended value of 0.5 . $\mathrm{H}_{2}$ was also supported because it was significant, with a significance level of less than 0.001 ( ${ }^{(}$significance level with 3 stars ${ }^{* * *}$ ).

Table 4: Hypothesis Testing

\begin{tabular}{|l|c|c|c|}
\hline \multicolumn{1}{|c|}{ Path Coefficients } & Hypothesis & Factor Loading & Significance \\
\hline Technological Marketing $\rightarrow$ Porter's Five Forces & $\mathrm{H}_{1}$ & $\begin{array}{c}-0.89 \\
\text { Not supported }\end{array}$ & ns \\
\hline Technological Marketing $\rightarrow$ SME Competitiveness & $\mathrm{H}_{2}$ & $\begin{array}{c}0.775 \\
\text { Supported }\end{array}$ & $\mathrm{c}^{\text {*** }}$ \\
\hline Porter's Five Forces $\rightarrow$ SME Competitiveness & $\mathrm{H}_{3}$ & $\begin{array}{c}-0.135 \\
\text { Not supported }\end{array}$ & ns \\
\hline
\end{tabular}




\section{Discussion and Conclusions}

This paper primarily sought to determine whether a linear relationship between the adoption of technological marketing (capability) and firm competitiveness and performance can be found. In addition, the paper aimed to ascertain whether or not PFF has a linear relationship with SME competitiveness. The research paper was also interested in investigating whether SMEs were using new and advanced technologies to market their products and to enhance their competitiveness.

The findings confirmed the significance of technological marketing, PFF and SME competitiveness in Buffalo City Metropolitan Municipality (BCMM). Most significantly the study established that there is a linear relationship between the adoption of new and advanced technologies (technological marketing capability) and SME competitiveness. This means a firm that adopts marketing technologies in Buffalo City Metropolitan Municipality can positively influence its sales growth, profitability and general performance. Hence, the establishment of the linear relationship validated $\mathrm{H}_{2}$. However, according to the findings, SMEs in BCMM do not use latest and accessible technologies to compete against each other.

Hence, the findings did not validate the existence of a significant influence of the adoption and development of technological marketing on Porter's five competitive forces (industry structure). More so, the invalidation and non-support of $\mathrm{H}_{1}$ suggests that there is no significant linear relationship between the adoption and development of new and advanced technological marketing and the competitiveness of SMEs (Porter's five forces). In line with this finding, $\mathrm{H}_{1}$ and $\mathrm{H}_{3}$ were not supported and remained invalidated. Therefore, the use of advanced technological marketing tools without other supporting non-technological strategies does not give a competitive edge to firms.

Conclusively, SMEs in the Buffalo City Metropolitan Municipality are adopting advanced technologies in marketing their products so as to improve performance in terms of sales growth, profitability and general performance. However, SME owners/managers are not adopting the technologies with a view to improve firm competitiveness as there is no linear relationship between the two. This therefore, implies that firms are using non-technological strategies to compete with each other. Consequently, the adoption and development of various marketing technologies by SMEs only improves their performance, without any increase on their competitive edge against other firms in the market.

\section{Managerial Implications}

The findings of the study are particularly important to SME owners/managers. Most importantly, the study provides a better understanding to firm owners/managers on the impact of marketing technologies on firm competitiveness and performance. The study highlights the relationships between marketing technologies and firm competitiveness, marketing technologies and PFF as well as firm competitiveness and PFF. Hence, the research helps SME owners/managers gain a better understanding of the benefits of adopting marketing technologies. This research study will assist SME owners/managers in decision making, especially on whether or not to adopt new and accessible marketing technologies. A positive impact of marketing technologies on competitiveness and performance encourages the owners/managers to adopt the technologies. However, a negative relationship deters SMEs from adopting the marketing technologies. This means a negative relationship entails negative returns on investment on acquiring the technologies. Hence, the study assists SMEs in making effective financial management decisions. This is vital as small firms have limited financial resources (Kauffmann, 2005:2).

With the boom in the use of advanced technologies in recent years, SME owners/managers need to make informed decisions based on scientific research on the use and development of such technologies and their capabilities. In the contemporary business world, the use of new and advanced technologies is regarded as being innovative. Innovative owners/managers can be assisted in weighing and considering the benefits and limitations of innovation, as reflected through their technological investments. Therefore, it is imperative that the SME owners/managers understand the benefits and limitations of innovation. This study can also help to minimise the fears of laggards on the use of new and advanced technologies. Therefore, the study helps to change the attitudes of laggards and innovative owners/managers. Also, a positive relationship either between adoption of marketing technologies and firm competitiveness or marketing technologies and firm performance will create a positive attitude towards the adoption of technologies. Furthermore, a negative relationship will cement the beliefs of laggards while reducing the adoption rate among innovative owners/managers.

The study has far-reaching effects on encouraging SME owners/managers to develop sustainable business models to efficiently and effectively drive their business processes. Both non-adoption and adoption has an impact on the efficiency and effectiveness of how the firms achieve their objectives, since, every business organisation seeks to be 
competitive, relevant and accessible. Therefore, non-adoption will entail the use of the traditional business model, while adoption means making use of the new business model that represents new and innovative ways of doing business. SME owners/managers need to use the relevant business model to remain relevant and achieve their objectives.

Although the initial objective of the study was to determine whether the adoption of marketing technologies can negatively influence firm competitiveness and performance in Buffalo City Metropolitan Municipality, the ultimate objective is to formulate recommendations to improve the contribution of SMEs to the national economy. This can only be possible after determining the relationships between technological marketing capability, Porter's five competitive forces and firm compettiveness. The recommendations are two-faced, with a view to improve both the demand and supply side of technological marketing capability policy formulation. These relate to recommendations to SMEs and recommendations to policy makers (government and quasi-government agencies).

\section{Future Research}

The research paper only targeted retail and manufacturing SMEs and omitted enterprises in other sectors of the economy. The research also only targeted SMEs in the Buffalo City Metropolitan Municipality, ignoring enterprises in other regions. Although this was necessary in the face of time and financial constraints, it is difficult to generalise the findings across all the provinces. This is partly because SMEs in different provinces face different operating conditions, as provincial governments are able to formulate different regulation policies for small firms. Future research must, therefore, target other sectors like mining and service sectors to determine whether the adoption of marketing technologies has a positive bearing on firm performance and competitiveness. Future researchers must also undertake research in other provinces of the country such as Gauteng, the Free State and Limpopo.

According to the findings presented herein, there is no positive relationship between the adoption of marketing technologies and firm competitiveness. Consequently, there is a need for future studies to investigate factors that have a positive bearing on the firm's competitiveness. This is because SMEs have to compete with large business organisations to stay in business (Maguire, et al., 2007:38). Although the results of the study indicated that the adoption of marketing technologies has a positive impact on firm performance, it is important to note that there are other non-technological factors that influence the performance of SMEs. Future studies must, therefore, also investigate non-technological factors that influence sales growth, profitability and general performance. Future researchers should also concentrate on the impact of individual marketing technologies on firm performance. This is because not all marketing technologies might have a positive linear relationship with firm performance. This will assist SMEs to acquire the appropriate marketing technologies, in future, without wasting financial resources by purchasing ineffective technologies.

\section{References}

Adeyemi, O. 2009. A Modern Approach to Marketing Management. The International Journal of Marketing Studies, 2(2), 2-14.

Anderson, J.C. \& Gerbing, D.W. 1988. Structural Equation Modelling in Practice: A Review and Recommended Two Step Approach. Psychological Bulletin, 103 (3), 411-423.

Baker, S. \& Bass, M. 2003. New Consumer Marketing. West Sussex: John Wiley \& Sons Ltd.

Boone, L.E. \& Kurtz, D.L. 1992. Contemporary Marketing. New York: Harcourt Brace Jovanovich Publishers.

De Klerk, S. \& Kroon, J. 2005. e-Commerce Adoption in South African Businesses. South African Journal of Business Management, 36(1), 33-40.

Galbreath, J. \& Galvin, P. 2008. Firm Factors, Industry Structure and Performance Variation: New Empirical Evidence to a Classical Debate. Journal of Business Research, 61(1), 109-117.

Ghazanfar, A., Mcgee, J. \& Thomas, H. 2000. The Impact of Technological Change on Industry Structure and Corporate Strategy: The Case of the Reprographics Industry in the United Kingdom. In the Management of Strategic Change ed. Andrew M. Pettigrew: Basil Blackwell.

Grant, R.M. 2002. Contemporary Strategy Analysis. $4^{\text {th }}$ Ed. Oxford: Blackwell Business.

Hellriegel, D., Jackson, S.E., Slocum, J., Staude, G., Amos, T., Klopper, K.B., Louw, L. And Oosthuizen, T. 2004. Management. South Ed. Cape Town: Oxford University Press.

Hollensen, S. 2003. Marketing Management: A Relationship Approach. Essex: Pearson Education Ltd.

Jain, S.C. 1997. Marketing Planning and Strategy. Ohio: South Western College Publishers.

Kauffmann, C. 2005. Financing SMEs in Africa. Working Paper.

Kotler, P. \& Keller, K.L. 2006. Marketing Management. New Jersey: Pearson Education.

Lamb, W.C. (Jr), Hair, J.F. (Jr). And Mcdaniel, C. 2002, Marketing, Ohio: South-Western Publishers.

Louw, L. \& Venter, P. 2010. Strategic Management: Developing Sustainability in Southern Africa. Cape Town: Oxford University Press.

Louw, L. 2008. Strategic Management: Winning in the Southern African Workplace. Cape Town: Oxford University Press Southern 
Africa (Pty) Ltd.

Maguire, S., Koh, S.C.L. And Magrys, A. 2007. The Adoption of e-Business and Knowledge Management in SMEs. An International Journal, 14 (1), 37-58.

Malcolm, M. And Martin, C. 2003. Marketing: A Complete Guide. New York: Palgrave Macmillan Ltd.

Masocha, R., Chiliya, N. \& Zindiye, S. 2011. The Impact of Technology on Competitive Marketing by Banks: A Case Study Approach. African Journal of Marketing Management Vol. 3(3), pp. 68-77,

McCartan-QUIN, D. \& CARSON, D. 2003. Issues which Impact upon Marketing in the Small Firms. Small Business Economics, 21(2).

Mcgee, J., Thomas, H. \& Wilson, D. 2005. Strategy Analysis and Practice. UK: McGraw-Hill.

Megginson, L.C., Byrd, M.J. \& Megginson, W.L. 2003. Small Business Management: An Entrepreneur's Guidebook. $4^{\text {th }}$ Ed. New York: McGraw-Hill.

Mol, J., Chiu, M.M. \& Wijnberg, N. (2012) Love Me Tender: new entry in popular music. Journal of Organizational Change Management, Vol. 25 No. 1, pp. 88-120

Porter, M.E. 1980. Competitive Strategy. New York: The Free Press.

Porter, M.E. 2001. Strategy and the Internet. Harvard Business Review, 79(3), 63-78.

Porter, M.E. 2008. The Five Forces That Shape Competition. Harvard Business Review, 80(2), 2-23.

Powell, T.C. \& Dent-Micallef, A. 1997. Information Technology as Competitive Advantage: The Role of Human, Business and Technology Resources. Strategic Management Journal, 18(5), 375-405.

Reedy, J. And Schullo, S. 2004. Electronic Marketing: Integrating Electronic. Australia: South Western Publishers.

Rodie, A.R. \& Martin, C.L. 2001. Competing in the service sector: the entrepreneurial challenge. Interantional Journal of Entrepreneurial Behaviour \& Research, Vol. 7 No. 1, pp.5-21.

Spanos, Y.E. \& Lioukas, S. 2001. An Examination into the Logic of Rent Generation: Contrasting Porter's Competitive Strategy Framework and the Resource-Based Perspective. Strategic Management Journal, 22(10), 907-934.

Strauss, J. \& Frost, A. 2001. e-Marketing, 3rd Ed. Upper Saddle River: Prentice Hall.

Swanepoel, J. 2007. The e of Marketing. Cape Town: Juta \& Co.

Trainor, K.J., Rapp, A., Beitelspacher, L.S. \& Schillewaert, N. 2011. Integrating Information Technology and Marketing: An Examination of Drivers and Outcomes of e-Marketing Capability. Journal of Industrial Marketing management, 40(1), 162-174.

Walker, O.C. (Jnr)., Mullins, J.W., Boyd, H.W. (Jnr). \& Larrèchè, J. 2006. Marketing Strategy-A Decision-Focused Approach. New York: McGraw Hill. 